удК 354.53.071(477)

\title{
Д.І.Горбатова
}

\section{ДІЯЛЬНІСТЬ ОРГАНІВ ВИКОНАВЧОЇ ВЛАДИ ЩОДО РЕАЛІЗАЦІЇ ПРАВА НА ОХОРОНУ ЗДОРОВ'Я}

Постановка проблеми. У сучасних умовах реалізація права на охорону здоров'я посідає важливе місце у забезпеченні здорового рівня життя громадян. Як важливий фактор розвитку держави у соціальному контексті відіграє показник здоров'я людини. Людиноцентристська спрямованість сучасної держави обумовлює особливе призначення охорони здоров'я, що є системою заходів, що реалізуються органами публічного управління.

Вітчизняна охорона здоров'я, яка на сьогоднішній час перебуває у стадії реформування, вимагає докорінних перетворень, котрі спрямовані на збереження й зміцнення життя та здоров'я населення, а також створення дієвих умов для реалізації передбаченого Конституцією України права на охорону здоров'я. Фактичний стан медицини має визначні досягнення, проте вітчизняна система охорони здоров'я охоплює різні проблеми інституційного, фінансового та технічного характеру загалом, що перешкоджає повноцінному впровадженню медичної реформи та надання населенню якісних медичних послуг. Проте започаткована медична реформа системи охорони здоров'я сприймається населенням як особливий інструмент модернізації сфери надання медичних послуг.

Аналіз останніх досліджень і публікацій. Теоретико-практичні проблеми адміністративного аспекту охорони здоров'я були досліджені в працях таких вчених: В.Б. Авер'янова, З.С. Гладуна, О.М. Єщука, О.С. Коваленко, В.Є. Ковригіної, П.Є. Лівака, 3.О. Надюка, О. Пунди, О.Г. Рогової, Л.М. Руснак та інших.

Метою статті є здійснення грунтовного аналізу адміністративно-правового компонента права на охорону здоров'я в Україні.

Виклад основного матеріалу дослідження. Право людини на охорону здоров'я це одне з головних серед природних, невіддільних, невідчужуваних та непорушних прав людини.

Необхідно відзначити, що Конституція України забезпечує кожному громадянину право на охорону здоров'я, медичну допомогу і медичне страхування [1]. Кожна людина наділяється правом захищати своє життя та здоров'я, життя та здоров'я інших осіб від незаконних посягань.

Адміністративно-правове регулювання права на охорону здоров'я в нашій державі забезпечується Конституцією України, Основами законодавства України про охорону здоров’я, Законами України «Про забезпечення санітарного та епідемічного добробуту населення», «Про захист населення від інфекційних хвороб», «Про державні фінансові гарантії медичного обслуговування населення», «Про підвищення доступності та якості медичного обслуговування у сільській місцевості», «Про психіатричну допомогу» та іншими нормативно-правовими актами, які прийняті відповідно до них.

Українське законодавство регламентує, що охорона здоров'я є системою заходів, яка здійснюється державними органами, закладами охорони здоров'я, фізичними 
особами-підприємцями, які здійснюють приватну медичну практику, медичними та фармацевтичними працівниками для збереження і поновлення фізіологічно-психологічних функцій особи, працездатності й соціальної активності особи.

Різноманітний підхід відносно визначення поняття «права на охорону здоров’я» існує й серед правників. Так, Л.О. Красавчикова вказує, що право на охорону здоров’ я $€$ системою зафіксованих державою регулятивних і охоронних адміністративноправових норм, якими урегульовуються відносини стосовно особистого немайнового блага - здоров'я громадянина [2, с. 24].

У свою чергу, О.О. Пунда розуміє право на охорону здоров'я у якості системи правових норм, які регламентують відношення щодо збереження, сприяння і зміцнення здоров'я [5, с. 82$]$.

Реформування системи реалізації права на охорону здоров'я охоплює собою право на медичну допомогу. Однак, внаслідок становлення України у напрямку публічно-сервісної держави відбувається перехід у сфері охорони здоров’я з отримання медичної допомоги на надання громадянам медичного обслуговування.

Можна відзначити, що право на охорону здоров'я складається із декількох компонентів: надання медичних послуг, оскарження до уповноважених державних органів у випадку порушення зазначеного права та контроль за його додержанням.

Таким чином, право на охорону здоров'я є системою закріплених та охоронюваних державою адміністративно-правових норм, якими урегульовуються відносини стосовно як громадяни можуть споживати природне благо - здоров'я, направлені на самостійне чи через інших осіб збереження, зміцнення, розвиток й відновлення належного рівня фізично-психологічного стану організму громадян у разі порушення.

Іншим аспектом досліджуваного права постає обов' язок уповноваженого суб'єкта забезпечувати дане право кожному громадянину. Суб'єктами, які забезпечують право на охорону здоров’я є Президент України, Верховна Рада України та Кабінет Міністрів України. А суб'єктами, які мають спеціальну компетенцію та безпосередньо реалізують державну політику у сфері охорони здоров'я виступають Міністерство охорони здоров’я України (далі - МО3 України) та новостворена Національна служба здоров'я України. У такий спосіб, право на охорону здоров'я здебільшого забезпечується та реалізується органами виконавчої влади. Діяльність органів виконавчої влади необхідна для реалізації та забезпечення конституційного права на охорону здоров'я й надання кожному громадянину можливість використовувати дане право. Однією з головних функцій органів виконавчої влади є захист прав та інтересів особи, що породжує реалізацію даного права через надання медичних послуг громадянам.

Президент та Верховна Рада України наділені широкими законотворчими та управлінськими повноваженнями у сфері охорони здоров'я, які передбачені чинним законодавством. У свою чергу, Кабінет Міністрів України є центральним колегіальним органом виконавчої влади, який очолює всю їі систему. Кабінет Міністрів організовує розроблення і реалізацію комплексних та цільових загальнодержавних програм, створює економічні, правові та організаційні механізми, що стимулюють ефективну діяльність у сфері охорони здоров'я, забезпечує розвиток мережі медичних закладів, укладає міжурядові угоди й координує міжнародне співробітництво 
з питань охорони здоров'я, а також в межах своєї компетенції здійснює інші повноваження покладені на органи виконавчої влади у сфері охорони здоров'я.

Відповідно до Положення МОЗ є головним органом у системі центральних органів виконавчої влади, що забезпечує формування та реалізує державну політику у сфері охорони здоров'я, захисту населення від інфекційних хвороб, протидії ВіЛ-інфекції/ СНІДу й іншим соціально небезпечним захворюванням, забезпечує формування та реалізує державну політику у сфері епідеміологічного нагляду (спостереження), забезпечує формування та реалізацію державної політики у сфері створення, виробництва, контролю якості й реалізації лікарських засобів, медичних імунобіологічних препаратів і медичних виробів, у сфері обігу наркотичних засобів, психотропних речовин, їх аналогів і прекурсорів, протидії їх незаконному обігу, а також забезпечує формування державної політики у сфері санітарного та епідемічного добробуту населення [3].

У якості основних завдань МОЗ України:

- формує та реалізує державну політику у сфері охорони здоров'я, протидії ВІЛ-інфекції/СНІДу й інших соціально небезпечних захворювань;

- реалізує політику у сфері епідеміологічного нагляду (спостереження);

- організовує та втілюе державну політику у сфері створення, виробництва, контролю якості й реалізації лікарських засобів, медичних імунобіологічних препаратів та медичних виробів, у сфері обігу наркотичних засобів, психотропних речовин, їх аналогів і прекурсорів, протидії їх незаконному обігу;

- організовує державну політику у сфері санітарного та епідемічного добробуту населення;

- координує діяльність органів виконавчої влади щодо обігу наркотичних засобів, психотропних речовин, їх аналогів та прекурсорів, протидії їх протиправному обігу [3].

На основі завдань, які стоять перед Міністерством охорони здоров'я, останне виконує декілька функцій - організаційну, прогнозуючу, координуючу, економічну і контролюючу.

Так, Міністерство охорони здоров'я здійснюе діяльність у виді організаційної функції, яка виявляється у створенні оптимальних умов задля ефективного функціонування системи охорони здоров'я внаслідок впорядкованого і раціонального використання ресурсів.

У своїй діяльності Міністерство охорони здоров'я розробляє державні соціальні нормативи та регламенти у сфері охорони здоров'я, наприклад, МОЗ затверджує порядки надання медичної допомоги, здійснює атестацію лікарів, проводить акредитацію закладу охорони здоров'я, що є обов'язковою для всіх лікувально-профілактичних закладів незалежно від відомчого підпорядкування, форми власності, профілю та рівня надання лікувально-профілактичної допомоги, надання ліцензій на власну медичну практику у сімейній медицині або педіатрії для ФОП-лікарів, здійснює організаційне керівництво структурними підрозділами системи охорони здоров'я тощо.

Прогнозуюча функція полягає у розробці обгрунтованих та доцільних висновків відносно подальших дій на базі вірогідних знань та інформації (прогнозування показників стану здоров'я населення, враховуючи стан середовища життедіяльності громадян). 
Функція координації визначає та стимулює основні напрями діяльності суб’єктів системи охорони здоров'я. Так, МОЗ координує діяльність закладів охорони здоров'я, науково-дослідних установ медичного профілю тощо.

Міністерство охорони здоров'я реалізує економічну функцію, яка полягає у реалізації фінансової та інвестиційної політики, що виявляється у процесі процес реорганізації закладу в комунальне некомерційне підприємство, регулювання підприємницької діяльності у сфері охорони здоров'я тощо.

Контрольні повноваження Міністерства охорони здоров'я зводиться до виявлення порушень, здійснення заходів відносно усунення недоліків в управлінні сферою охорони здоров'я - контроль за додержанням санітарного законодавства, державних стандартів, критеріїв і вимог, а також здійснення контролю за додержанням умов ліцензії на провадження господарської діяльності з медичної практики тощо.

Разом з Міністерством охорони здоров'я України діє низка інших суб'єктів реалізації права громадян на охорону здоров'я, які функціонують на рівні областей, районів, міст. Усі вони втілюють та гарантують право громадян на охорону здоров'я та якісне медичне обслуговування.

У 2017 р. було утворено спеціальний орган виконавчої влади у сфері охорони здоров'я - Національну службу здоров'я України. Діяльність даної інституції спрямовується та координується Кабінетом Міністрів України через Міністра охорони здоров’я, який реалізує державну політику у сфері державних фінансових гарантій медичного обслуговування населення.

Головною метою діяльності Національної служби здоров'я України є забезпечення єдиного національного замовлення медичних послуг і лікарських засобів відповідно до програми медичних гарантій. Національна служба здоров'я України у якості основних завдань веде моніторинг, здійснює аналіз та прогноз потреб громадян у медичних послугах й лікарських засобах, здійснює замовлення послуг у медичних закладів і лікарів-ФОП відповідно до програми медичних гарантій, розробляє програмні проекти медичних гарантій для населення, пропонує тарифікацію медичних послуг, укладає, вносить зміни й припиняє договори щодо медичного обслуговування громадян, здійснює відшкодування вартості ліків; здійснює контроль над цільовим й ефективним використанням коштів згідно з програмою медичних гарантій, зокрема, перевіряє додержання медичними закладами та лікарями приватної медичної практики програмних умов й договорів про медичне обслуговування громадян, забезпечує роботу електронної системи охорони здоров'я [4].

Висновки. Отже, проведений аналіз стосовно реалізації права на охорону здоров'я свідчить про те, що право на охорону здоров'я реалізується органами виконавчої влади, насамперед, Кабінетом Міністрів України, Міністерством охорони здоров'я України та Національною службою здоров'я України, ключовим завданням яких постає забезпечення прав та інтересів громадян та їх захист й охорона зокрема. Новостворена Національна служба здоров'я має забезпечувати та реалізовувати медичну реформу, взаємодіяти з іншими державними органами, бути у ролі оператора, який контрактуватиме закупівлю медичних послуг, укладає договори з медичними закладами та лікарями-ФОП, забезпечує надання якісного медичного обслуговування для громадян. У загальному виді специфікою реалізації права на охорону здоров’я 
органами виконавчої влади є діяльність держави в особі її органів, що спрямована на повноцінне проведення та втілення медичної реформи, надання громадянам якісних медичних послуг та здійснення інших заходів, які направлені на удосконалення сфери охорони здоров'я.

\section{Jimepamypa:}

1. Конституція Украіни від 28 червня 1996 р. № 254к/96-BP. URL: http://zakon3.rada.gov.ua/ laws/show/254к/96-вр

2. Красавчикова Л.О. Понятие и система личных, не связанных с имущественными правами граждан (физических лиц) в гражданском праве Российской Федерации : автореф. дис. ... д-ра юрид. наук. Екатеринбург, 1994. 43 с.

3. Про затвердження Положення про Міністерство охорони здоров'я України : Постанова Кабінету Міністрів України від 25 березня 2015 р. № 267. URL: https://zakon.rada.gov.ua/laws/show/ 267-2015-п

4. Про утворення Національної служби здоров'я України : Постанова Кабінету Міністрів України від 27 грудня 2017 р. № 1101 URL: https://zakon.rada.gov.ua/laws/show/1101-2017-п

5. Пунда 0.0. Поняття та зміст права на здоров'я. Вісник Хмельницького інституту регіонального управління та права. 2003. № 3-4 (7-8). С. 79-84

\section{Анотація}

Горбатова Д. І. Діяльність органів виконавчої влади щодо реалізації права на охорону здоров'я. Стаття.

Статтю присвячено діяльності органів виконавчої влади щодо реалізації права на охорону здоров’я. Основна увагу в статті приділено функціям та повноваженням Кабінету Міністрів України, Міністерства охорони здоров'я України, Національної служби здоров'я України у здійсненні медичного реформування. Зроблено висновок, що на сьогоднішній час діяльність органів виконавчої влади має відбуватись узгоджено та послідовно шляхом надання громадянам якісних медичних послуг й здійснення інших заходів, які направлені на удосконалення сфери охорони здоров’я.

Ключові слова: адміністративно-правове забезпечення, органи виконавчої влади, охорона здоров’я, Міністерство охорони здоров’я України, Національна служба здоров'я України.

\section{Аннотация}

Горбатова Д. И. Деятельность органов исполнительной власти по реализации права на охрану здоровья. - Статья.

Статья посвящена деятельности органов исполнительной власти по реализации права здравоохранения. Основное внимание в статье уделяется функциям и полномочиям Кабинета Министров Украины, Министерства здравоохранения Украины, Национальной службы здоровья Украины в осуществлении медицинского реформирования. Сделан вывод, что на сегодняшнее время деятельность органов исполнительной власти должно происходить согласованно и последовательно путем предоставления гражданам качественных медицинских услуг и осуществления других мероприятий, направленных на совершенствование сферы здравоохранения.

Ключевые слова: административно-правовое обеспечение, органы исполнительной власти, здравоохранение, Министерство здравоохранения Украины, Национальная служба здоровья Украины.

\section{Summary}

Horbatova D. I. Activity of executive bodies on the realization of the right to health protection. Article.

The article is devoted to the activity of executive authorities in the implementation of the right to health care. The focus of the article is on the functions and powers of the Cabinet of Ministers of Ukraine, the Ministry of Health of Ukraine, and the National Health Service of Ukraine in the implementation of medical reform. It has been concluded that, to date, the activities of the executive authorities should be carried out in a coordinated and consistent manner by providing citizens with high-quality medical services and other measures aimed at improving the healthcare sector.

Key words: administrative-legal support, executive bodies, health care, Ministry of Health of Ukraine, National Health Service of Ukraine. 